\title{
A FORMAÇÃO PELA INFORMAÇÃO
}

Paula Amado*

SÍNTESE - Este artigo tem como objetivo mostrar como a Congregação Pobres Servos da Divina Providência, mais precisamente o Centro Social Padre Calábria, vem desenvolvendo através da sua revista $A$ Ponte, a formação do cidadão autônomo, flexível, mostrando assim a importância da comunicação na formação do cidadão.
ABSTRACT - This article aims to show how the Congregation Pobres Servos da Divina Providencia, more precisely the Padre Calábria Social Center, develops the formation of the autonomous, flexible citizen, through its magazine A Ponte, thus showing the importance of communication in the formation of the citizen.

A informação tem-se tornado a chave de todo conhecimento. As mudanças tecnológicas no mundo contemporâneo mostram de uma forma bastante visível que a comunicação é a principal forma de criar cidadãos autônomos, flexiveis, como exige essa nova demanda do mundo do trabalho.

Sem se excluir desse ritmo de informações, o Centro Social Padre Calábria, uma escola de ofício católica, criada na década de sessenta pelos padres da Congregação Pobres Servos da Divina Providência, na Rua Aracaju 470, Porto Alegre, também entra nesse processo de divulgação da informação através da criação da revista $A$ Ponte, como forma de manter a comunidade ligada aos acontecimentos do Centro, e da Congregação Pobre Servos da Divina Providência. Esse objetivo da revista se encontra claramente nesta passagem retirada da revista. "A Ponte surge unicamente para nos comunicar e reencontrar os amigos".

Desde 1974, quando foi fundada, até à atualidade, a revista tem uma periodicidade bimestral e é editada pela própria Escola de Artes Gráficas do Centro Social.

Quanto à sua forma, A Ponte é constituída de várias colunas, em que se abordam assuntos diversos, desde pequenas informações até assuntos referentes à política, educação, religião, problemas sociais e outros.

Graduanda em Ciências Sociais e bolsista de iniciação científica - FAPERGS, junto ao Projeto Integrado "Urbanidade e cidadania: um processo de formação e instauração de saberes, sob a orientação da professora Julieta Beatriz Ramos Desaulniers (PUCRS).

1 In revista $A$ Ponte n 1 Ano I, 1974 p. 3.

\begin{tabular}{|l|l|l|l|l|l|} 
VERITAS & Porto Alegre & v. 42 & $\mathrm{n}^{\circ} 2$ & Junho 1997 & p. 273-275 \\
\hline
\end{tabular}


Essa revista pertence a uma congregação religiosa cujo objetivo está referido num dos seus números, onde se assinala que "o objetivo da nossa congregação é chegar aos menores pobres para promovê-los socialmente através de uma formação cultural e profissional que os prepare para enfrentar a vida na contingência sócio-econômica do Brasil de hoje".

Nós estamos vivendo uma realidade peculiar a todos os países em desenvolvimento, estamos vivendo com o Brasil a pujante arrancada para o bem-estar social, e com este Brasil estamos colaborando, de um lado reduzindo a marginalização menoril, e de outro lado preparando mão de obra especializada, que permite acompanhar o processo de industrialização do país [...].

O objetivo da escola é dar a estes jovens uma chance, que de outra forma não a teriam, de vencerem na vida com um trabalho honesto e com uma profissão rendosa, fazer deles jovens capazes de assumir, sem complexos, o lugar que lhes compete no vertiginoso processo de desenvolvimento nacional" ${ }^{2}$

Os temas abordados pela revista não poderiam deixar de seguir os objetivos preconizados pela congregação, que enfatizam a questão da formação do cidadão consciente e participativo. A preocupação com a formação do cidadão encontra-se em vários trechos como o que se segue:

“A confusão ideológica é total, as certezas não mais existem, os valores são todos eles contestados, a objetividade filosófica apenas uma utopia, a verdade não passa apenas de um fato subjetivo.

Os problemas se apresentam maiores que as nossas próprias capacidades de para atendê-los [...].

Chega um momento, na vida de cada individuo, assim como de um grupo, de uma sociedade, de um país, que chamamos de "maturidade". É o estado adulto a que correspondem determinados e precisos deveres da participação.

A ninguém é permitido se omitir, sob pena de permanecer eternamente criança, levada pela mão de outros, para onde quer e, mais freqüentemente, para onde não quer.

É o momento da tomada de consciência que faz cada um exclamar "chegou a minha vez" [...].

Não cometamos a sólita, cômoda ingenuidade de pensarmos que, o que acontece fora da nossa casca, não nos interessa, pois assim agindo estaremos declinando de responsabilidade, pelo que, num futuro mais próximo haveremos do nos arrepender, pois se o mundo tornou-se uma aldeia, $o$ que acontece no outro hemisfério nos interessa e muito profundamentel Nem pensemos que, dando um voto mais ou menos consciente e responsável aos quinze de novembro, teremos liberado a nossa consciência de um peso indigeșto, pois se a democracia é participação ela não se limita a um voto a cada quatro anos [...]."

A preocupação de formar o cidadão está bem visível na revista $A$ Ponte, de forma que ele não permaneça apático aos problemas da sociedade, mas que participe, dando o seu parecer nas diversas questões abordadas. Através da informação procura-se colocar em prática os objetivos da congregação: expandir, socializar e, fundamentalmente formar o cidadão.

Verifica-se ainda que os temas abordados na revista $A$ Ponte são priorizados de acordo com o momento que se vive no país e no mundo. Exemplo disso foi o Ano Internacional da Criança bastante enfocado pela revista: "Ano internacional da criança, dados e questionamento":

\footnotetext{
Ver revista A Ponte n², Ano I, 1974, p. 5.

In revista $A$ Ponte $\mathrm{n}^{9} 4, \mathrm{Ano}$ V, 1978, p. 12.
} 
"Com o início do ano de 1979, foi aberto o Ano Intemacional da criança, e como todas as revistas, jornais, rádio e televisão, já debateram amplamente este assunto; nossa revista também quer levar aos leitores alguns questionamentos sobre este assunto. Assunto, aliás, de vital importância para trabalharmos entre os menores e principalmente os mais necessitados. Com o Ano Internacional da Criança, o Brasil pensa em amenizar a miséria, o abandono e promover uma vida mais digna àqueles que sẵo o futuro da pátria.

Segundo dados de 1976, o Brasil possui uma população de vinte e cinco milhões de menores carentes, dos quais dois milhōes não possuem atendimento algum, estando totalmente abandonados à "mãe natureza" [...].

Um outro dado alarmante é que dos vinte e cinco milhões de menores carentes, onze milhões são carentes excepcionais que não possuem portanto, inteligência normal.

São criaturas que sofrem sem culpa. Nem os pais, na maioria das vezes, são culpados. A culpa pode ser nossa. Bem instalados, contentes de amontoar planos que só fiquem planos.

Culpada é a sociedade aburguesada que vê nesses necessitados somente incômodo para o seu bem-estar, sociedade esta que é muitas vezes também a causa do aumento desta população marginalizada" ."

A questão política é muito importante, na medida em que é fundamental que todos participem nas decisões, mas para que isso aconteça é necessário que o cidadão conheça os seus direitos e obrigações. Para deixar bem clara a preocupação com a questão política, transcreve-se o seguinte texto extraído da revista:

“É lamentável que muitas pessoas ostentam indiferença para com a vida política do pais, como lamentável é ver que outras vendem seu voto. Talvez a quem os explora, a troco de uma pequena vantagem momentânea, como donativo, ou um churrasco.

Falta amadurecimento politico, provocado às vezes, propositadamente, no interesse de quem tira desta situação vantagens.

Agora os partidos politicos vêm aí. Após a reformulação partidária, vários surgiram e todos já se apresentam com os seus quadros organizativos e programas de ação. Eles apresentam ideais diferentes, maneiras distintas de analisar a sociedade atual e, partindo disso propõem-se aos meios suas linhas de ação para alcançar aquele que é ou deveria ser o objetivo de todos, isto é o bem comum. A abertura democrática, se realmente perseguida e dejxar amadurecer, é uma grande vantagem". ${ }^{\circ}$

Seguindo a dinâmica da congregação e do próprio Centro Social Padre Calábria, ou seja, tentar acompanhar o desenvolvimento tecnológico, conseqüentemente, as transformações no mundo do trabalho, e, acima de tudo, influenciar na formação do cidadão, a revista $A$ Ponte, vem tentando incentivar 0 cidadão na sua forma de atuar, junto às várias questões sociais que lhe dizem respeito, incluindo sua participação nas atividades de interesse do próprio Centro Calábria.

A formação veiculada na revista visa formar o cidadão a partir de noções e valores que tendem a provocar mudanças na comunidade em que 0 Centro atua. Isso sem dúvida implica o fortalecimento do capital religioso e até a transformação deste em outros capitais, ${ }^{6}$ consolidando assim a estrutura da congregação.

A variedade de assunto nela abordada e a forma como é feita levam a concluir que, além de ser uma revista informativa, é acima de tudo formativa, estreitamente associada aos interesses do Centro Social Padre Calábria.

\footnotetext{
Ver revista $A$ Ponte n 1 Ano VI, 1979, p. 12.

Ver revista A Ponte $n^{2} 5$ Ano VII, 1980, p. 10-11.

In revista Veritas, v. 40, $\mathrm{n}^{2} 158$ junho 1995, p. 235-242.
} 